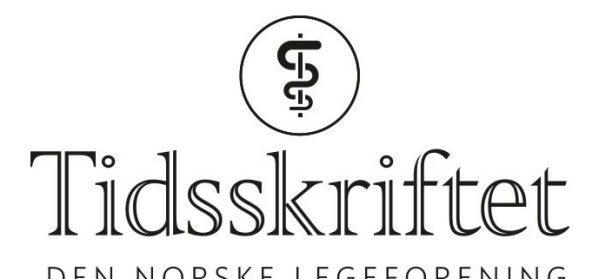

DEN NORSKE LEGEFORENING

\title{
Hysterektomi ved St. Olavs hospital 1989-2014
}

ORIGINALARTIKKEL

\section{SILJE EILERTSEN DENSTAD}

Kvinneklinikken

St. Olavs hospital

Hun har bidratt med datainnsamling for 1999 og 2004, analyse, tolking, litteraturs $ø$, utarbeiding/revisjon og godkjenning.

Silje Eilertsen Denstad (f. 1980) er lege i spesialisering

Forfatter har fylt ut ICMJE-skjemaet og oppgir ingen interessekonflikter.

\section{SILJE AASEN}

Det medisinske fakultet

Norges teknisk-naturvitenskapelige universitet

Hun har bidratt med datainnsamling for 2014, analyse, tolking, litteraturs $\emptyset$, utarbeiding/revisjon og godkjenning.

Silje Aasen (f. 1988) er medisinstudent og arbeider som medisinstudent med lisens på Gynekologisk poliklinikk, St. Olavs hospital

Forfatter har fylt ut ICMJE-skjemaet og oppgir ingen interessekonflikter.

\section{ANETTE MAISTRY ØSTREM}

Oslo kommunale legevakt

Hun har bidratt med datainnsamling for 2010 og utarbeiding av manuskript.

Anette Maistry Østrem (f. 1988) er lege.

Forfatter har fylt ut ICMJE-skjemaet og oppgir ingen interessekonflikter.

\section{VIVI BAKKEHEIM}

Revmatologisk avdeling

St. Olavs Hospital

Hun har bidratt med datainnsamling for 1989 og 1994 og utarbeiding av manuskript.

Vivi Bakkeheim (f. 1977) er spesialist i revmatologi.

Forfatter har fylt ut ICMJE-skjemaet og oppgir ingen interessekonflikter.

\section{GURO HAUGEN FOSSUM}

Klinikk for hode, hals og rekonstruktiv kirurgi

Oslo universitetssykehus, Rikshospitalet

Hun har bidratt med datainnsamling for 1989 og 1994 og utarbeiding av manuskript.

Guro Haugen Fossum (f. 1978) er lege i spesialisering.

Forfatter har fylt ut ICMJE-skjemaet og oppgir ingen interessekonflikter.

\section{METTE HAASE MOEN}

E-post: Mette.moen@ntnu.no

Det medisinske fakultet

Norges teknisk-naturvitenskapelige universitet 
Hun har bidratt med idé, utforming/design, tolking av data, litteratursøk og utarbeiding/revisjon av selve manuset.

Mette Haase Moen (f. 1944) er spesialist i fødselshjelp og kvinnesykdommer og professor emerita. Forfatter har fylt ut ICMJE-skjemaet og oppgir ingen interessekonflikter.

\section{BAKGRUNN}

Hysterektomi er en av de vanligste gynekologiske operasjonene. Operasjonsmetodene har endret seg de siste decenniene. Nye utredningsmuligheter og alternative behandlingsmetoder har kommet til. Hensikten med denne studien er å beskrive utviklingen av hysterektomi utført på benign indikasjon ved St. Olavs hospital i perioden 1989-2014.

\section{MATERIALE OG METODE}

Totalt 903 pasienter er inkludert fra årgangene 1989, 1994, 1999, 2004, 2010 og 2014. Journalopplysninger om demografi, preoperativ utredning og behandling, operasjonsindikasjon, operasjonsmetode, operasjonstid, komplikasjoner, liggetid og sykmeldingsperiode er registrert retrospektivt ved gjennomgang av pasientjournaler.

\section{RESULTATER}

Fra 1989 til 2014 ble preoperativ diagnostikk ved abrasio redusert fra $68 \%$ til $4 \%$, mens pipellemetoden økte fra 8\% til 68\%. Ultralydundersøkelse ble i 2014 utført hos 97\%. Hysterektomier utført med laparotomi ble redusert fra 107 i 1989 til 37 per 100 ooo kvinner i 2014, mens vaginale og laparoskopiske hysterektomier til sammen økte i samme periode fra tre til 81 per 100 ooo kvinner. I 2014 ble nesten halvparten av hysterektomiene utført med robotassistert laparoskopi. Parallelt med overgangen fra laparotomi til mindre invasive metoder ble det registrert mindre blødning og kortere ligge- og sykmeldingstid.

\section{FORTOLKNING}

Operasjonsmetoder for hysterektomier har gått fra åpen laparotomi til mindre invasive metoder som vaginal og laparoskopisk kirurgi. Robotassistert laparoskopisk hysterektomi er nå den vanligste operasjonsmetoden. Mindre invasive inngrep er gunstig for pasientsikkerhet og rekonvalesens.

Hysterektomi er en av de vanligste gynekologiske operasjonene. De vanligste indikasjoner for hysterektomi er blødningsforstyrrelser, myomer, smerter, descens og endometriose.

I Norge ble det i 2013 utført totalt 4632 hysterektomier (1), hvorav ca. 75\% antas å være på benign bakgrunn. Livstidsrisiko for at en kvinne får fjernet livmoren på grunn av godartet årsak er tidligere angitt å være ca. 12\% (2), men er sannsynligvis noe lavere i dag med flere alternative behandlingsmetoder. Siden tidlig på 20oo-tallet har det vært en nedgang i antall hysterektomier i hele Norden (3). Tendensen har vært spesielt tydelig i Finland, hvor hysterektomiraten er halvert i perioden 1990-2012 (3). I Norge har raten (antall hysterektomier per år per 100000 kvinner i alle aldere) i årene 2004-13 falt fra 226 til 183 (1, 4). Nedgangen kan forklares ved at det er kommet alternative behandlingsmetoder som gestagenspiral, endometrieablasjon, embolisering og hormonbehandling av myomer. Operasjonsmetodene ved hysterektomi har de siste decenniene endret seg fra laparotomier til vaginale inngrep og laparoskopisk kirurgi, inklusive robotassistert laparoskopisk kirurgi. Denne utviklingen ser vi både på universitetssykehus og regionale sykehus $(5,6)$. Laparoskopisk hysterektomi ble innført i Norge i begynnelsen av 1990-årene (5). St. Olavs hospital tok i bruk metoden i 2006 og innførte robotassistert hysterektomi på benign indikasjon i 2010.

Når nye operasjonsmetoder innføres ved et sykehus, er kvalitetskontroll av metoden viktig. 
I andre nordiske land finnes hysterektomiregistre hvor operasjonsmetoder og resultater fortløpende registreres $(3,7,8)$. Norge har ikke et slikt landsdekkende register. Det er derfor viktig at det enkelte sykehus har oversikt over egne operasjonsmetoder og komplikasjoner. Vi har sett på utviklingen av hysterektomi utført på benign indikasjon ved St. Olavs hospital i perioden 1989-2014. Oppmerksomheten har vært rettet mot preoperativ utredning, indikasjon for operasjon, operasjonsmetoder, komplikasjoner, liggetid og sykmelding.

\section{Materiale og metode}

Studien er en retrospektiv gjennomgang av pasientjournaler i kalenderårene 1989, 1994, 1999, 2004, 2010 og 2014. Kvinnene ble identifisert via manuell gjennomgang av operasjonsprotokollen i 1989, 1994, 1999 og 2004, og med søk i elektronisk operasjonsplanlegger i 2010 og 2014. Søket inneholdt følgende operasjonskoder: LCD11 (laparoskopisk assistert vaginal hysterektomi), LCC11 (laparoskopisk subtotal hysterektomi), LCDoo (abdominal hysterektomi), LCDo1 (total laparoskopisk hysterektomi), LCD1o (vaginal hysterektomi) og LCC10 (supravaginal hysterektomi). Vi gjennomgikk pasientjournalen til alle kvinnene som ble identifisert og ekskluderte pasienter der man preoperativt mistenkte malignitet. Av totalt 947 pasienter identifisert med de aktuelle operasjonskodene, fant vi ikke pasientjournal hos 44 (4,6\%) (19 fra 1989, 12 fra 1994, fem fra 1999, åtte fra 2004). Vi har ikke registrert hvor mange journaler som totalt ble gjennomgått. For 2014 inkluderte vi også pasienter operert på Orkdal sjukehus, da denne enheten siden 2012 har vært underlagt St. Olavs hospital. Rater for hysterektomi er beregnet ut fra antall hysterektomier på benign indikasjon per 100 ooo kvinner i alle aldere i vårt geografiske område.

Vi registrerte følgende informasjon om pasientene: alder (år), paritet (antall fødsler), menopause (ja/nei), preoperativ utredning (bildediagnostikk/endometriehistologi), diagnose og behandlingsfors $ø \mathrm{k}$ (endometrieablasjon/gestagenspiral), operasjonsmetode, operasjonstid (knivtid i minutter), per- og postoperative komplikasjoner, hemoglobinfall (preoperativ $\mathrm{Hb}$ minus laveste postoperative $\mathrm{Hb}$, angitt i g/dl), blodtransfusjon (ja/nei), reoperasjon (ja/nei), postoperativ diagnose, liggedøgn og antall sykmeldingsdager. Peroperative komplikasjoner er definert som intraoperativ blødning $\geq 1$ ooo $\mathrm{ml}$ og blære-, ureter- eller tarmskade erkjent under operasjon. Informasjon om operasjonstid og peroperativ blødning ble hentet fra anestesijournalen. Postoperativ periode er definert som tiden etter avsluttet operasjon til seks uker postoperativt, og kun komplikasjoner registrert i pasientens sykehusjournal er tatt med. Data om sykmelding er hentet fra pasientjournal (epikrise), eventuelle forlengelser hos fastlege er ikke registrert. Vi har definert konvensjonell laparoskopi som total laparoskopisk hysterektomi, laparoskopisk assistert supravaginal hysterektomi og laparoskopisk assistert vaginal hysterektomi.

Alle pasienter som ifølge operasjonsbeskrivelsen ble hysterektomert på benign bakgrunn ble inkludert. Det innebærer at også pasienter som uventet fikk påvist kreft postoperativt er inkludert i studien.

Studien ble forelagt Regional komité for medisinsk og helsefaglig forskningsetikk (REK), som vurderte at dette var en kvalitetsstudie. Det var dermed ikke nødvendig med formell godkjenning.

Opplysningene ble registrert i en database som ble oppbevart på minnepenn i låst arkivskap. Dette var godkjent av Det medisinske fakultet, Norges teknisknaturvitenskapelige universitet. Statistiske beregninger ble gjort i SPSS 21 (IBM).

\section{Resultater}

Vi identifiserte 947 kvinner som ble operert på benign indikasjon disse seks årene. Av disse hadde vi tilgang til 903 journaler for uthenting av informasjon. Flest kvinner ble hysterektomert i 1999 (186 kvinner per 100 ooo kvinneår), hvoretter raten falt med 37\% (til 118 per 100000 ) i 2014 (fig 1 , tab 1 ). 

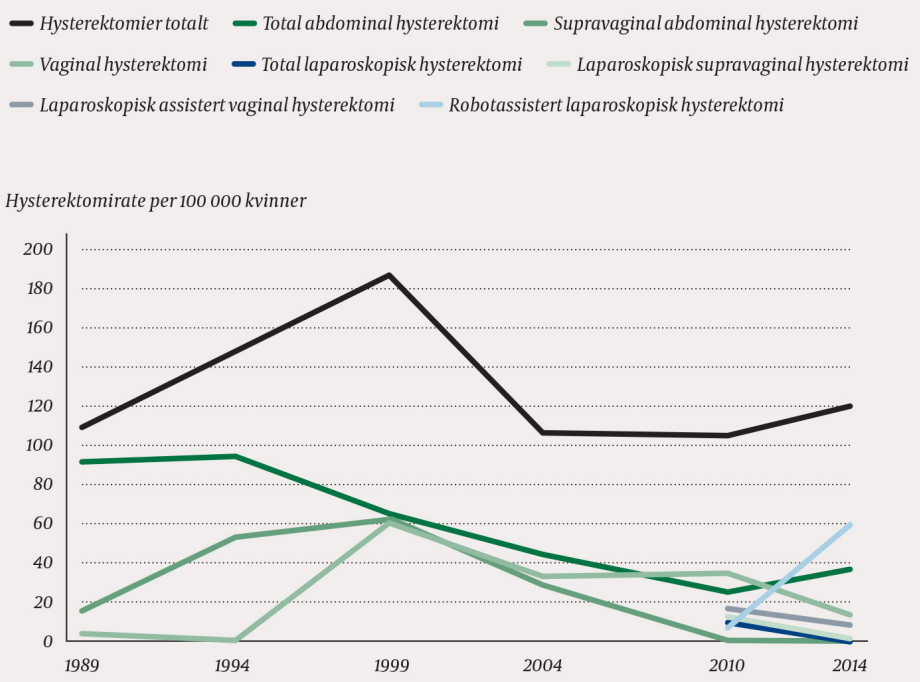

Figur 1 Hysterektomirate (per 10oooo kvinner i alle aldere i regionen) fordelt på ulike operasjonsmetoder ved St. Olavs hospital 1989-2014 $(N=903)$

\section{Tabell 1}

Antall, rater (per 100 ooo kvinner i alle aldere) og median alder for hysterektomi på benign indikasjon ved St. Olavs hospital i perioden 1989-2014

\begin{tabular}{|c|c|c|c|c|c|c|c|c|c|c|c|c|}
\hline & \multicolumn{2}{|c|}{1989} & \multicolumn{2}{|l|}{1994} & \multicolumn{2}{|l|}{1999} & \multicolumn{2}{|c|}{2004} & \multicolumn{2}{|l|}{2010} & \multicolumn{2}{|l|}{2014} \\
\hline & Antall & Rate & Antall & Rate & Antall & Rate & Antall & Rate & Antall & Rate & Antall & Rate \\
\hline $\begin{array}{l}\text { Totalt antall } \\
\text { hysterektomier }\end{array}$ & 114 & 110 & 159 & 149 & 204 & 186 & 120 & 106 & 128 & 105 & 178 & 118 \\
\hline $\begin{array}{l}\text { Total } \\
\text { abdominal } \\
\text { hysterektomi }\end{array}$ & 94 & 91 & 101 & 94 & 71 & 65 & 51 & 45 & 32 & 26 & 55 & 36 \\
\hline $\begin{array}{l}\text { Supravaginal } \\
\text { abdominal } \\
\text { hysterekomi }\end{array}$ & 17 & 16 & 57 & 53 & 67 & 61 & 33 & 29 & 1 & 1 & 1 & 1 \\
\hline $\begin{array}{l}\text { Vaginal } \\
\text { hysterektomi }\end{array}$ & 3 & 3 & 1 & 1 & 66 & 60 & 36 & 32 & 43 & 35 & 21 & 14 \\
\hline $\begin{array}{l}\text { Laparoskopisk } \\
\text { supravaginal } \\
\text { hysterekomi }\end{array}$ & - & & - & & - & & - & & 20 & 16 & 12 & 8 \\
\hline $\begin{array}{l}\text { Total } \\
\text { laparoskopisk } \\
\text { hysterektomi }\end{array}$ & - & & - & & - & & - & & 11 & 9 & - & \\
\hline $\begin{array}{l}\text { Laparoskopisk } \\
\text { assistert } \\
\text { vaginal } \\
\text { hysterektomi }\end{array}$ & - & & - & & - & & - & & 14 & 12 & 1 & 1 \\
\hline $\begin{array}{l}\text { Robotassistert } \\
\text { laparoskopisk } \\
\text { hysterektomi }\end{array}$ & - & & - & & - & & - & & 7 & 6 & 88 & 58 \\
\hline $\begin{array}{l}\text { Median alder } \\
\text { (spredning) }\end{array}$ & $\begin{array}{r}46 \\
(28-87) \\
\end{array}$ & & $\begin{array}{r}47 \\
(31-79) \\
\end{array}$ & & $\begin{array}{r}49 \\
(26-85) \\
\end{array}$ & & $\begin{array}{r}48,5 \\
(33-91) \\
\end{array}$ & & $\begin{array}{r}45 \\
(34-76) \\
\end{array}$ & & $\begin{array}{r}48 \\
(29-92) \\
\end{array}$ & \\
\hline
\end{tabular}

Til og med 2004 var laparotomi den vanligste operasjonsmetoden for hysterektomi. I 2010 ble flest operert vaginalt, 35 per 100 ooo kvinneår, og 37 per 100 ooo ble operert med ulike konvensjonelle laparoskopiske teknikker (fig 1, tab 1). Robotassistert laparoskopisk hysterektomi ble tatt i bruk på St. Olavs hospital i november 2010, og økte til 58 per 100 ooo kvinneår i 2014, om lag halvparten av alle hysterektomiene dette året. I samme periode falt raten av konvensjonell laparoskopisk hysterektomi med 76\% til 9 per 100 ooo kvinneår og vaginale med 6o\% til 14 per 100 ooo (fig 1 , tab 1).

Pasientenes medianalder for hele perioden var 47 år (spredning 26-92 år), med en tilfeldig variasjon de respektive årene (tab 1). Totalt 199 (22\%) av kvinnene var postmenopausale ved operasjon. I overkant av en tredel av pasientene (333 kvinner) fikk fjernet ovariene eller restovariet, henholdsvis $27 \%$ av de premenopausale og $70 \%$ av de postmenopausale. 
Et $\emptyset$ kende antall kvinner gjennomgikk alternative behandlingsfors $\emptyset \mathrm{k}$ med endometrieablasjon og/eller hormonspiral før hysterektomi (fig 2). Vi fant $\varnothing$ kende bruk av bildediagnostikk med CT, MR eller vaginal ultralyd i utredningen. I 2014 ble alle pasientene utredet med bildediagnostikk, de fleste med ultralyd, mot kun $25 \%$ i 1989 (fig 3 ). Bruk av pipelle for prøvetaking av endometriet har gradvis avløst abrasio, som nå stort sett kun brukes når enkel endometriediagnostikk ikke kan gjennomføres (fig 3).

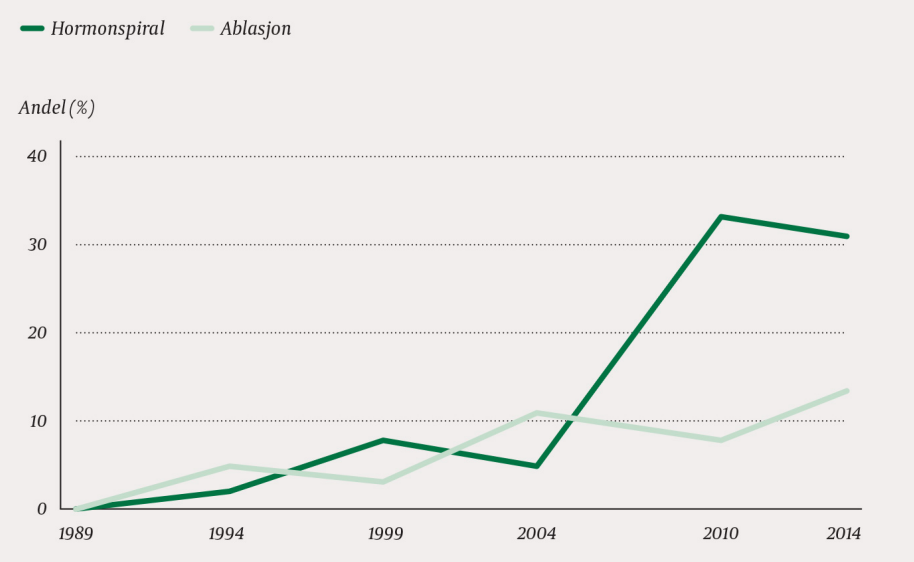

Figur 2 Andel pasienter som hadde fått hormonspiral og endometrieablasjon før hysterektomi på benign indikasjon ved St. Olavs hospital 1989-2014 ( $N=903)$

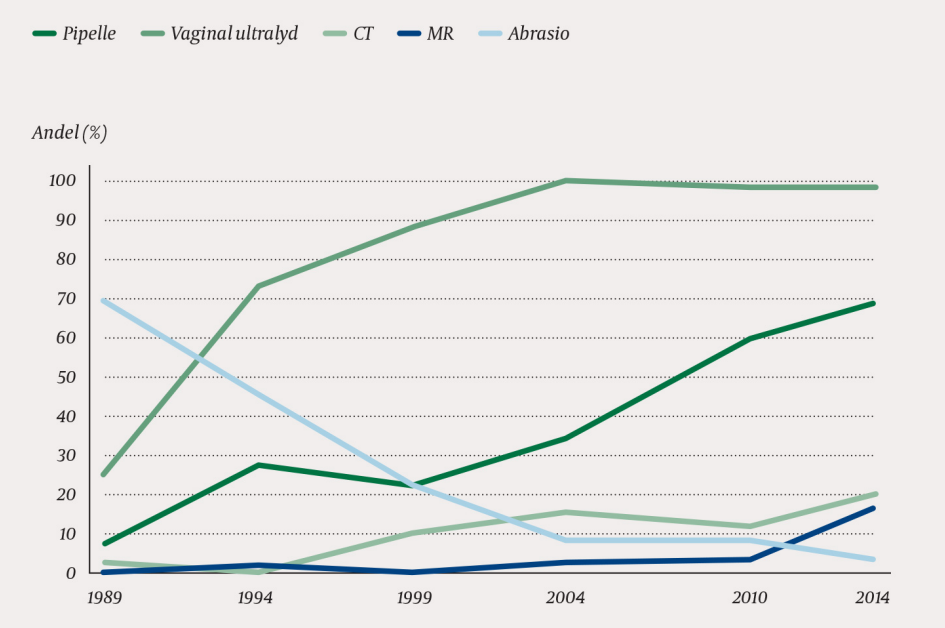

Figur 3 Andel pasienter som er blitt utredet med pipelleprøve av endometriet, vaginal ultralyd, CT, MR og abrasio før hysterektomi på benign indikasjon ved St. Olavs hospital 1989-2014 (N=903)

Totalt $516(57,1 \%)$ av alle pasientene hadde myom som preoperativ diagnose, $445(49,3 \%)$ hadde blødningsforstyrrelse, 146 (16,2\%) hadde smerter og 82 (9,1\%) benign ovarialpatologi. 21 av pasientene (2,3\%) fikk uventet en malign diagnose postoperativt. Tre av disse var sarkomer. Det utgjør o,8\% av alle med myom som preoperativ diagnose.

Operasjonstiden falt fra 101 til 83 minutter fra 1989 til 1999 parallelt med at supravaginale og vaginale operasjoner ble mer vanlig ( $\operatorname{tab} 2$ ). I 2010, etter innføring av konvensjonell laparoskopisk hysterektomi, økte operasjonstiden igjen til 129 minutter. I 2014, da halvparten av hysterektomiene ble utført med robot, falt operasjonstiden til 110 minutter. Antall postoperative ligged øgn falt fra åtte dager i 1989 til tre dager i 2014. Samtidig ble også antall sykmeldingsdager redusert fra 32 i 1989 til 21 i 2014. Den største endringen skjedde mellom 2004 og 2010, samtidig som laparotomi i stor utstrekning ble erstattet med laparoskopi $(\operatorname{tab} 2)$. 


\section{Tabell 2}

Gjennomsnittlig operasjonstid og liggetid ( \pm standard deviasjon (SD)) samt median sykmeldingstid ved hysterektomier på benign indikasjon ved St. Olavs hospital fra 1989 til $2014(N=903)$

\begin{tabular}{|c|c|c|c|c|c|c|c|}
\hline & 1989 & 1994 & 1999 & 2004 & 2010 & 2014 & P-verdi \\
\hline $\begin{array}{l}\text { Operasjonstid } \\
\text { (min) } \\
\pm \mathrm{SD} \\
\end{array}$ & $\begin{array}{r}101 \\
\pm 30\end{array}$ & $\begin{array}{r}88 \\
\pm 27\end{array}$ & $\begin{array}{r}85 \\
\pm 32\end{array}$ & $\begin{array}{r}101 \\
\pm 41\end{array}$ & $\begin{array}{r}129 \\
\pm 54\end{array}$ & $\begin{array}{r}112 \\
\pm 38\end{array}$ & $<0,001$ \\
\hline $\begin{array}{l}\text { Liggetid (døgn) } \\
\pm \text { SD }\end{array}$ & $\begin{array}{r}7,8 \\
\pm 3,0 \\
\end{array}$ & $\begin{array}{r}7,5 \\
\pm 2,5 \\
\end{array}$ & $\begin{array}{r}6,9 \\
+2,4 \\
\end{array}$ & $\begin{array}{r}6,0 \\
\pm 2,2 \\
\end{array}$ & $\begin{array}{r}2,2 \\
\pm 2,1 \\
\end{array}$ & $\begin{array}{r}2,7 \\
+4,9 \\
\end{array}$ & $<0,001$ \\
\hline $\begin{array}{l}\text { Sykmelding } \\
\text { (dager) }(\mathrm{N}=659) \\
\text { (spredning) }\end{array}$ & $\begin{array}{r}30,0 \\
(5-60)\end{array}$ & $\begin{array}{r}35,0 \\
(22-74)\end{array}$ & $\begin{array}{r}31,0 \\
(10-54)\end{array}$ & $\begin{array}{r}36,5 \\
(10-92)\end{array}$ & $\begin{array}{r}14,0 \\
(3-101)\end{array}$ & $\begin{array}{r}17,0 \\
(7-73)\end{array}$ & $<0,001$ \\
\hline
\end{tabular}

${ }^{1}$ Enveis ANOVA

Operasjonstid, peroperativ blødningsmengde, liggetid og median sykmelding for de ulike operasjonsmetodene varierte. Laparotomiene (både total og supravaginal) hadde størst peroperativ blødning, lengst ligge- og sykmeldingstid, mens konvensjonell laparoskopi hadde lengst operasjonstid (fig 4 ). Totalt 63 pasienter (7\%) hadde peroperative komplikasjoner (tab 3). I tillegg ble 157 (17\%) pasienter registrert med postoperative komplikasjoner. De fleste komplikasjonene var mindre alvorlige. Alvorlige postoperative komplikasjoner var blant annet blødning (3\%), ileus (o,8\%) og sepsis (o,6\%). En pasient (ca. o,1\%) døde i det postoperative forløpet som følge av flere komplikasjoner. Reoperasjon ble foretatt på 19 pasienter (2,1\%), hvorav sju skyldtes tarmperforasjon, intraabdominal blødning, sårruptur eller ureterskade. Mindre inngrep, som drenasje av vaginaltoppshematom, er også registrert som reoperasjon.

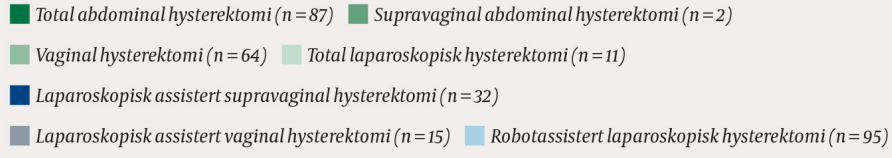

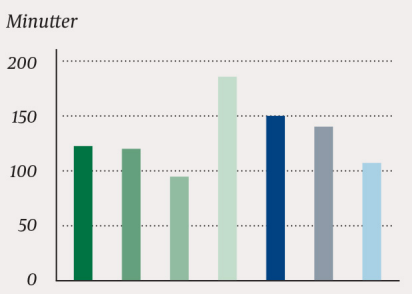

Operasjonstid

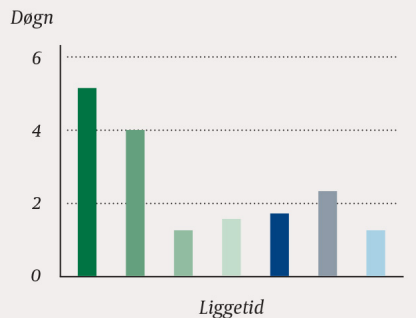

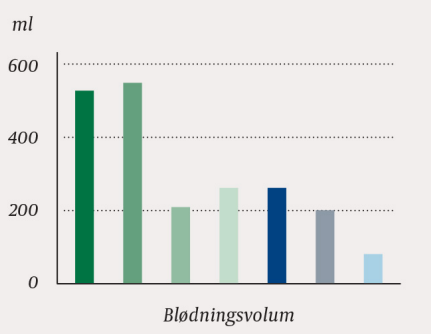

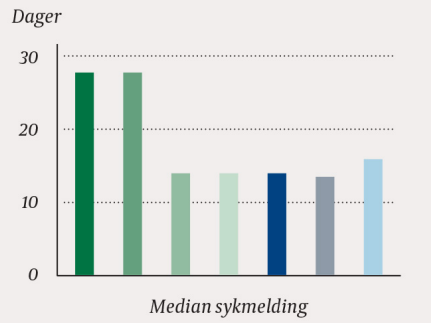

Figur 4 Gjennomsnittlig operasjonstid, peroperativt blødningvolum og liggetid samt median sykmeldingstid ved St. Olavs hospital 2010-14 for ulike operasjonsmetoder 
Antall hysterektomier, gjennomsnittlig fall i hemoglobin (Hb-fall), behov for transfusjon, peroperative kirurgiske komplikasjoner og reoperasjon ved ulike operasjonsmetoder ved hysterektomi på benign indikasjon ved St. Olavs hospital 1989-2014

\begin{tabular}{|c|c|c|c|c|c|}
\hline & $\begin{array}{r}\text { Antall } \\
\text { Pasienter }\end{array}$ & Hb-fall $^{1}$ & ransfusjon & $\begin{array}{r}\text { Peroperative } \\
\text { kirurgiske } \\
\text { komplikasjoner }\end{array}$ & eoperasjon \\
\hline & & $\begin{array}{r}\text { Gj.snitt } \pm \\
\text { SD }\end{array}$ & Antall (\%) & Antall (\%) & Antall (\%) \\
\hline $\begin{array}{l}\text { Total abdominal } \\
\text { hysterektomi }\end{array}$ & 404 & $\begin{array}{r}3,1 \pm \\
1,4\end{array}$ & $41(10,1)$ & $42(10)^{2}$ & $10(2,5)$ \\
\hline $\begin{array}{l}\text { Supravaginal } \\
\text { abdominal } \\
\text { hysterektomi }\end{array}$ & 176 & $\begin{array}{r}2,9 \pm \\
1,3\end{array}$ & $8(4,5)$ & $11(6)^{3}$ & $2(1,1)$ \\
\hline $\begin{array}{l}\text { Vaginal } \\
\text { hysterektomi }\end{array}$ & 170 & $\begin{array}{r}2,5 \pm \\
1,0\end{array}$ & $6(3,5)$ & $8(5)^{4}$ & $5(2,9)$ \\
\hline $\begin{array}{l}\text { Total laparoskopisk } \\
\text { hysterektomi }\end{array}$ & 11 & - & - & 1 (9) & - \\
\hline $\begin{array}{l}\text { Laparoskopisk } \\
\text { assistert } \\
\text { supravaginal } \\
\text { hysterektomi }\end{array}$ & 32 & $\begin{array}{r}2,1 \pm \\
1,4\end{array}$ & - & $1(3)$ & - \\
\hline $\begin{array}{l}\text { Laparoskopisk } \\
\text { assistert vaginal } \\
\text { hysterektomi }\end{array}$ & 15 & $\begin{array}{r}1,5 \pm \\
1,4\end{array}$ & - & - & - \\
\hline $\begin{array}{l}\text { Robotassistert } \\
\text { laparoskopisk } \\
\text { hysterektomi }\end{array}$ & 95 & $\begin{array}{r}1,9 \pm \\
1,0\end{array}$ & $1(1,1)$ & - & $2(2,1)$ \\
\hline
\end{tabular}

${ }^{1} \mathrm{Hb}$ fall $=\mathrm{Hb}$ preoperativt minus laveste $\mathrm{Hb}$, angitt i $\mathrm{g} / \mathrm{dl}, \mathrm{p}<\mathrm{0,05}$

${ }^{2} 6$ tarmskader/ureterskader/blærerifter og 36 blødninger

${ }^{3} 2$ blærerifter og 9 blødninger

${ }^{4}$ hvorav 7 blødninger

\section{Diskusjon}

Vår studie fra St. Olavs hospital viser at flest kvinner ble hysterektomert i 1999 og at om lag like mange kvinner ble hysterektomert i 2014 som i 1989. Operasjonsmetodene har de siste 25 årene endret seg fra laparotomi til mindre invasive inngrep som vaginal hysterektomi og laparoskopi. I 2014 er robotassistert laparoskopi vanligste metode. Parallelt er det blitt færre peroperative komplikasjoner, mindre behov for transfusjon samt betydelig kortere ligge- og sykmeldingstid.

Styrkene ved studien er at det ble brukt samme registreringsskjema for alle årganger og at data ble registrert i en felles database. Det er høy grad av kliniske detaljer, spesielt om operasjonsteknikker, slik at vi kan vurdere bruk og komplikasjoner ved de forskjellige teknikkene. En svakhet er at dataregistrering ut fra journalnotater ble foretatt av medisinstudenter med begrenset innsikt i kliniske rutiner og metoder. Det var imidlertid kontinuitet i registreringsarbeidet, idet to av forfatterne (SED og MHM) fortløpende foretok kvalitetssikring av uthentede data. Da kvalitet på journalnotater kan variere, har vi lagt størst vekt på operasjonskoder, organskader, blodtap, operasjonstid, liggetid og sykmeldingstid. En annen mulig svakhet er at registreringene ikke har vært kontinuerlige, men i hovedsak vært utført hvert femte år. Derved kan vi gå glipp av nyanser og detaljer som for eksempel innlæringsproblemer ved bruk av nye operasjonsmetoder.

Vår undersøkelse fra St. Olavs hospital viste en økning i hysterektomirate frem til 1999, 
deretter en reduksjon på 37\% frem til 2014. Tilsvarende utvikling er også sett i de øvrige nordiske landene, med mest markant reduksjon av hysterektomiraten, om lag 50\%, i Finland fra 1990 til 2012 (3). I Sverige var raten for perioden 1987-2003 høyest i 1999, deretter inntrådte et fall (9). En dansk oversiktsartikkel fra perioden 1977-2011 viste at hysterektomiraten fluktuerte, men falt den siste femårsperioden (10). Det er imidlertid vanskelig å sammenligne operasjonsrater i ulike studier, da beregningene varierer i forhold til hvilke operasjonsindikasjoner som er brukt (operasjoner på benign og malign indikasjon), eller hvordan raten er beregnet (alle kvinner i befolkningen, kvinner over 18 år eller aldersjusterte rater). Vi har ikke funnet studier på hysterektomirate fra andre norske sykehus.

Tendensen til å velge mindre invasive operasjonsmetoder gjenfinnes også i andre studier (3, $6,9,10)$. Generelt anbefales vaginal hysterektomi dersom dette er mulig (11-13). En Cochrane-rapport fra 2015 viste at vaginal hysterektomi medfører færre komplikasjoner, lavere kostnader og kortere ligge- og sykmeldingstid enn de øvrige operasjonsmetodene (11). Hvis vaginal hysterektomi ikke er mulig, ved for eksempel samtidig adnexpatologi, avansert endometriose eller adheranser, anbefales laparoskopiske metoder fremfor laparotomi fordi laparotomi medfører lengre ligge- og sykmeldingstid, flere postoperative infeksjoner og større peroperativ blødning (11-13).

Det er et paradoks at det ved innføring av nye legemidler kreves grundig utprøvning i flere faser, og hvor nye produkter klart må vise fordeler i forhold til tidligere behandling, både med hensyn til effekt, bivirkninger og økonomi. Slike krav stilles ikke når det dreier seg om kirurgisk behandling. Entusiastiske pionerer tar i bruk ofte kostbart utstyr, og utredning av kostnad-nytte-effekt kommer i annen rekke. De få studier som foreligger har ikke vist noen fordeler med robotkirurgi sammenlignet med konvensjonell laparoskopi $(11,14)$. De positive erfaringene med robotassistert hysterektomi som ble innført ved St. Olavs hospital i 2010, kan ikke uten videre sammenlignes med konvensjonell laparoskopi. Hittil har robotassistert laparoskopi vært utført av et fåtall erfarne overleger, mens øvrige laparoskopiske inngrep har vært utført av alle leger, også leger i spesialistutdanning. Robotassistert laparoskopi er regnet for å være vesentlig dyrere enn konvensjonell laparoskopi, mest på grunn av pris på utstyr og vedlikehold. Kostnaden påvirkes av mange faktorer, inkludert kirurgens erfaring og kompleksiteten ved prosedyren. En randomisert studie der man sammenlignet komplikasjoner og kostnader ved robotassistert kirurgi med laparoskopisk hysterektomi, fant man at iavdelingersom allerede har anskaffet utstyr for robotassistert hysterektomi, er metodene like kostnadskrevende (15).

Korrekt preoperativ diagnose er viktig for valg av operasjonsmetode. I de fleste tilfeller var det samsvar mellom pre- og postoperativ diagnose. Mest fryktet er at det som preoperativt antas å være et benignt myom, viser seg å være et malignt uterussarkom. Laparoskopisk hysterektomi ved benigne myomer utføres med intraabdominal morcellering (findeling) av myomet. Ved malignitet kan morcelleringen medføre spredning av cancerceller (16). Vi fant at hos 21 kvinner (2,3\%) ble det uventet påvist malignitet ved histologien. Det var tre tilfeller av sarkom blant 516 antatt benigne myomer (8\%). I et materiale fra Ullevål sykehus var diagnosen sarkom en uventet diagnose i ca. 5,5\% av operasjonene for antatt benignt myom (17). I et amerikansk materiale på 7500 antatt benigne hysterektomier ble det påvist $2,7 \%$ malignitet, herav $2,2 \%$ sarkomer (18).

Alle kirurgiske inngrep medfører risiko for komplikasjoner. Vår studie viser samme frekvens og type av peroperative komplikasjoner som i en finsk studie (3), bortsett fra hyppigere forekomst av blødning i vårt materiale, noe som kan forklares av en høyere andel laparotomier her. Postoperative komplikasjoner er vanskelige å sammenligne, da definisjoner på komplikasjoner ikke er standardiserte. Det ble registrert ett dødsfall blant de 903 hysterektomiene (ca. o,1\%). Dette er en påminnelse om at det må være klar indikasjon for kirurgi, som her var til stede ut fra anbefalinger i Veileder i generell gynekologi (19). Risiko for død ved hysterektomi er i en større studie angitt til o,o6-0,21\%, med lavest andel blant pasienter operert av gynekologer som utførte mer enn ti hysterektomier per år 
(20).

Det er opplagt en fordel for pasientene å bli utredet og operert med mindre invasive metoder. Alle kirurgiske inngrep medfører risiko for komplikasjoner og bør overvåkes nøye. Nasjonale og internasjonale helseregistre er den beste måten å samle slik informasjon. Det foreligger i Norge et laparoskopiregister (21), men registeret er ufullstendig og ikke et generelt register for hysterektomi. Det er avgjørende å ha data om fordeler og ulemper ved de ulike operasjonsmetoder, så kvinnen kan være med på å bestemme operasjonsmetode og eventuelt også sykehus for operasjon.

\section{HOVEDBUDSKAP}

I perioden 1989-2014 varierte operasjonsraten for hysterektomi ved St. Olavs hospital mellom 110 og186 per 100 ooo

Andelen laparoskopiske inngrep økte og utgjorde i 2014 omkring halvparten av alle operasjonene

Ligge- og sykmeldingstiden i forbindelse med disse inngrepene ble i samme periode omtrent halvert

I 2014 ble nesten alle pasientene utredet med ultralyd og pipelle før operasjon

\section{LITTERATUR:}

1. NOMESCO. Health statistics for the Nordic Countries 2013.

https://norden.diva-portal.org/smash/get/diva2:941584/FULLTEXTo1.pdf(1.6.2017).

2. Moen MH. Ulik praksis ved hysterektomi. Tidsskr Nor Laegeforen 2004; 124: 767. [PubMed]

3. Jokinen E, Brummer T, Jalkanen J et al. Hysterectomies in Finland in 1990-2012: comparison of outcomes between trainees and specialists. Acta Obstet Gynecol Scand 2015; 94: 701 - 7 .

[PubMed][CrossRef]

4. Helsestatistik for de nordiske lande 2004. København: NOMESCO, 2006.

5. Oma J. Hvilke faktorer avgjør metodevalget ved hysterektomi på benign indikasjon? Tidsskr Nor Laegeforen 2004; 124: 792 - 4. [PubMed]

6. Goderstad JM, Lieng M, Busund B. Kirurgisk behandling av benigne gynekologiske lidelser. Tidsskr Nor Legeforen 2009; 129:146o -3. [PubMed][CrossRef]

7. Dansk Hysterektomi og Hysteroskopi Database. National Årsrapport 2014. http://www.sundhed.dk/content/cms/11/4711_dhhd_aarsrapport_2014_endelig.pdf.(1.2.2017).

8. Stjerndahl J, Löfgren M, Renström B. Årsredovisning avseende hysterektomi utförd på benign indikation år 2014 .

http://www.gynop.org/rapportering/rapporter/Gynop\%C3\%85rsrapportHysterektomiOp\%C3\%85r2014.p df. (1.2.2017).

9. Lundholm C, Forsgren C, Johansson AL et al. Hysterectomy on benign indications in Sweden 1987-2003: a nationwide trend analysis. Acta Obstet Gynecol Scand 20o9; 88: 52 - 8. [PubMed][CrossRef]

10. Lykke R, Blaakær J, Ottesen B et al. Hysterectomy in Denmark 1977-2011: changes in rate, indications, and hospitalization. Eur J Obstet Gynecol Reprod Biol 2013; 171:333 - 8. [PubMed][CrossRef]

11. Aarts JW, Nieboer TE, Johnson $\mathrm{N}$ et al. Surgical approach to hysterectomy for benign gynaecological disease. Cochrane Database Syst Rev 2015; 8: CDoo3677. [PubMed]

12. Walters MD. Choosing a route of hysterectomy for benign disease. 2016.

http://www.uptodate.com/contents/choosing-a-route-of-hysterectomy-for-benign-disease?sourcemachineLearning\&searchhysterectomy\&selectedTitle=1 150\&sectionRank=1\&anchorH801890408 H8018904O8 (1.2.2017).

13. ACOG Committee Opinion No. 444: choosing the route of hysterectomy for benign disease. Obstet 
Gynecol 2009; 114: 1156 - 8. [PubMed][CrossRef]

14. Wright JD, Ananth CV, Lewin SN et al. Robotically assisted vs laparoscopic hysterectomy among women with benign gynecologic disease. JAMA 2013; 309: 689 - 98. [PubMed][CrossRef]

15. Lönnerfors C, Reynisson P, Persson J. A randomized trial comparing vaginal and laparoscopic hysterectomy vs robot-assisted hysterectomy. J Minim Invasive Gynecol 2015; 22: 78 - 86.

[PubMed][CrossRef]

16. Kirste U. Behandling av benigne gynekologiske tilstander. Tidsskr Nor Legeforen 2009; 129:1446. [PubMed][CrossRef]

17. Lieng M, Berner E, Busund B. Risk of morcellation of uterine leiomyosarcomas in laparoscopic supracervical hysterectomy and laparoscopic myomectomy, a retrospective trial including 4791 women. J Minim Invasive Gynecol 2015; 22: 410 - 4. [PubMed][CrossRef]

18. Mahnert N, Morgan D, Campbell D et al. Unexpected gynecologic malignancy diagnosed after hysterectomy performed for benign indications. Obstet Gynecol 2015; 125:397- 405.

[PubMed][CrossRef]

19. Eikeland G, Tingulstad S, Veddeng A. Ovarialcyster. 2009.

http://legeforeningen.no/Fagmed/Norsk-gynekologisk-forening/Veileder-arkiv-utgatte-versjoner/veil eder-i-generell-gynekologi-2009/(1.2.2017).

20. Boyd LR, Novetsky AP, Curtin JP. Effect of surgical volume on route of hysterectomy and short-term morbidity. Obstet Gynecol 2010; 116: 909 - 15. [PubMed][CrossRef]

21. Norsk gynekologisk endoskopiregister. Årsrapport 2015.

http://www.kvalitetsregistre.no/registers/547/resultater (1.2.2017).

Publisert: 4. september 2017. Tidsskr Nor Legeforen. DOI: 10.4045/tidsskr.16.026o

Mottatt 18.3.2016, første revisjon innsendt 21.10.2016, godkjent 1.6.2017.

(C) Tidsskrift for Den norske legeforening 2020. Lastet ned fra tidsskriftet.no 